\title{
INSULIN AND HYDROCORTISONE INFLUENCES ON CULTURED RAT TONGUE EPITHELIUM
}

\author{
C. T. HANKS \\ Department of Oral Pathology, School of Dentistry, University of Michigan, \\ Ann Arbor, MI 48109, U.S.A.
}

\begin{abstract}
Summary - Rat tongue epithelium was separated from underlying connective tissue by trypsinization, dispersed into single cells and small clusters and plated on cellulose acetate-nitrate filters, collagen gels or plastic substrate in serum-supplemented media. Morphologically, abundance of growth and stratification of epithelium was greatest on floating collagen gels, intermediate on plastic and least on the filters. Cultures on the plastic substrate were used to test the effects of insulin, hydrocortisone, dimethyl sulphoxide, glucose and soybean trypsin inhibitor upon epithelial outgrowth. Cultures were plated at the same density, grown to partial confluency, and analysed with a superimposed point lattice to determine the fraction of total subsurface covered. Cells cultured $1.25-5 \times 10^{5} \mathrm{cells} / \mathrm{cm}^{2}$ in serum-supplemented $\alpha \mathrm{MEM}$ or McCoy's $5 \mathrm{~A}$ media produced the best outgrowth. Additional insulin supplementation at $40 \mu \mathrm{g} / \mathrm{ml}$ gave better outgrowth than 400 or $4 \mu \mathrm{g} / \mathrm{ml}$ within the first week. Insulin at $40 \mu \mathrm{g} / \mathrm{ml}$ also gave better outgrowth than a mixed insulin-hydrocortisone supplement at three different levels or than hydrocortisone supplement alone at three different levels. When 0.5 per cent DMSO was added to any of these supplementary formulas, epithelial outgrowth was reduced compared with the same formulae without DMSO. Addition of three times the formula level of glucose aiso reduced epithelial outgrowth. Addition of soybean trypsin inhibitor to $\propto \mathrm{MEM}$ supplemented with insulin, but not fetal calf serum, caused increased epithelial outgrowth. These findings helped define appropriate conditions for cell attachment, migration, proliferation and differentiation of primary rat tongue epithelial cultures.
\end{abstract}

\section{INTRODUCTION}

Epithelial cells from skin and oral mucosa have been cultured by both explant (Jepsen, 1974; Ijuhin, Rose and Mahan, 1976) and cell plating methods (Vaughn and Bernstein, 1971; Fusenig and Worst, 1975; Pruniéras, Delescluse and Regnier, 1976). In both cases, cell division occurs in the first and second strata adjacent to the substrate and differentiation of daughter cells results in a multilayered epithelium which keratinizes and mimics the tissue source morphologically. The major difficulty in studying factors influencing epithelial cell growth and differentiation in explant cultures is the presence of associated dermal or submucosal connective tissue. The presence of these connective tissue elements makes the interpretation of experimental results more complex rather than simpler.

Many investigators have demonstrated in organ and tissue culture the permissive influence, within limits, of dermal cells or connective tissue factors upon basal cell orientation, cell proliferation, and migration and differentiation of embryonic tissues such as chick embryonic cornea (Weiss and Matoltsy, 1959), chick skin (Wessells, 1964), pancreas (Bernfield, 1970; Pictet et al., 1975) and kidney (Nordling et al., 1977), as well as on post-embryonic skin and oral mucosa of rodents (Billingham and Silvers, 1967) and human adult epidermis (Briggaman and Wheeler, 1971). These findings and others strongly suggest that factors derived from the connective tissue play a permissive role in terms of both substrate and growth factors. In an effort to understand the growth and differentiation capacity of isolated epithelial cells, epi- dermal cells have been cultured from cell suspensions derived by trypsinizing newborn skin (Fusenig and Worst, 1975; Marcelo et al., 1978). Maintenance of primary plated cultures, as well as subcultures, in a differentiated state over long periods without degeneration. has been a problem (Fusenig and Worst. 1975; Karasek, 1975) and has not been achieved except in studies which have incorporated connective tissue cells (Rheinwald and Green, 1975). The objective of culturing epithelial cells in the absence of connective tissue elements is to simulate the effects of these elements on isolated epithelial cells by artificial methods so that the cultures will mimic epithelial architecture and function. All mature epithelia are non-vascular and derive their nutrients from an underlying connective tissue through a basal lamina. Many of the substances that diffuse to the basal epithelial cells are probably derived from serum which contains a large number of growth factors (e.g., mitogenic polypeptides), which may have a major influence during prenatal development, as well as the peptide and steroid hormones. The actions of other hormones such as insulin, hydrocortisone and thyroxine have been investigated extensively in cultured cell lines (Cuatrecasas, 1974; Cristofalo, 1974; Pardee, 1975).

Few investigators have reported the effects of hormones on the primary culture of integumental epithelium (Rheinwald and Green, 1975; Marcelo et al., 1978) although they have been studied extensively in other primary epithelial systems such as mammary gland, lens and liver (Reddan et al., 1975; Richman et al., 1976; Hallowes et al., 1977). 


\section{MATERIALS AND METHODS}

\section{Materials}

Male Sprague-Dawley rats (Spartan Research Animals, Haslett, MI), 3 weeks to 3 months old, were used as the source of the cultured cells. All nutrient media, fetal calf serum (FCS), 1-glutamine (200 mM), penicillin streptomycin $(\mathrm{P} / \mathrm{S} ; 10,000 \mathrm{IU} / \mathrm{ml}$ and $10,000 \mu \mathrm{g} / \mathrm{ml}$, respectively), trypan blue and powdered salts for phosphate buffered saline (PBS) and Hanks balanced salt solution (Hanks BSS) were obtained from Grand Island Biological Co. (Grand Island, NY). Plastic T-25 flasks (Falcon ${ }^{\circledR}$ 3012) and 24-well dishes (Falcon 3008) were products of Bioquest Division of Becton, Dickinson and Co. (Cockeysville, MD). Cellulose acetate-nitrate filters were bought from Millipore Corporation (Bedford, MA) and polycarbonate filters from Nuclepore Corporation (Pleasanton, CA). Chick embryo extract and dessicated chicken plasma were obtained from Difco Laboratories (Detroit, MI). Trypsin $(2 \times$ crystallized bovine pancreatic), soybean trypsin inhibitor, insulin (crystalline bovine pancreatic, $24 \mathrm{IU} / \mathrm{mg}$ ) and hydrocortisone-21-sodium succinate, Trizma Base and Trizma $\mathrm{HCl}$ and leucine-methoxy-B-naphthylamide $\mathrm{HCl}$ were obtained from Sigma (hemical Co. (St. Louis, MO). Tetrazotized disorthoanisidine (fast blue B) was from Nutritional Biochemicals Corp. (Cleveland, $\mathrm{OH}$ ), dimethylsulphoxide (DMSO, silylation grade) from Pierce Chemical Co. (Rockford, IL), sucrose from Swartz/Mann Division of Becton, Dickinson \& Co. (Orangeburg, NY) and Ficoll 400 from Pharmacia Fine Chemicals AB (Uppsala, Sweden). Giemsa powder was obtained from Fisher Scientific Co. (Fair Lawn, NJ) and glutaraldehyde, sodium cacodylate, osmium tetroxide, Epon 812 and Araldite 6005 from Ernest F. Fullam Inc. (Schenectady, NY).

\section{Primary cultures from suspensions of epithelial cells}

Rat tonguc cpithelium from both ventral and dorsal surfaces were obtained under ether anaesthesia. The resected tongues were divided into dorsal and ventral halves, which were further subdivided lengthwise into thirds and floated in 0.25 per cent trypsin in Hanks BSS, pH 8.0, for $18 \mathrm{~h}$ at $4^{\circ} \mathrm{C}$, according to a modification of Szabo's technique (Szabo, 1955). Each group of 7 tongues was treated with $25 \mathrm{ml}$ of trypsin solution. The epithelium was then gently separated with stainless steel forceps from the connective tissue and stirred in Eagle minimum essential medium (MEM) with 5 per cent heat-treated FCS for $1 \mathrm{~h}$ at room temperature. The suspended cells were pipetted off and centrifuged at $1000 \mathrm{rev} / \mathrm{min}$ for $5 \mathrm{~min}$ and washed a second time in medium. Approximately $3.5 \times 10^{6}$ cells were obtained from each tongue. In some experiments, tongue epithelial cells from seven animals were placed on a discontinuous Ficoll gradient (Farb, Dykes and Lazarus, 1978). The gradient contained $10 \mathrm{ml}$ of 12 per cent Ficoll, $10 \mathrm{ml}$ of 14 per cent Ficoll and $5 \mathrm{ml}$ of 16 per cent Ficoll, from top to bottom, all suspended in Medium 199 and placed gently in a $30 \mathrm{ml}$ centrifuge tube. This tube was spun at $1200 \mathrm{~g}$ for $30 \mathrm{~min}$ and the "cleaned" pellet was analysed using trypan blue exclusion and haemocytometer. Those cells pelleted in the bottom of the gradient were mainly small basal cells. However, they grew no better than cells taken directly from suspension and plated after washing twice in PBS. Therefore, for all subsequent experiments, epithelium was stripped from the connective tissue after overnight trypsinization in the refrigerator and the suspended epithelial cells were washed with PBS before being plated in nutrient media.

Epithelial cells were plated under various conditions and at cell concentrations between $1.25-5 \times 10^{5}$ cells $/ \mathrm{cm}^{2}$ in 24 -well dishes or in T-25 flasks. The tissue culture dishes were incubated at $37^{\circ} \mathrm{C}$ in a humid atmosphere of 95 per cent air and 5 per cent $\mathrm{CO}_{2}$; the medium was changed every 3 days. The medium for most of these experiments was the alpha modification of MEM ( $\alpha \mathrm{MEM})$ with either 10 or 20 per cent heattreated FCS, and supplemented with fresh glutamine $(12.5 \mu \mathrm{l} / \mathrm{ml})$ and $\mathrm{P} / \mathrm{S}(12.5 \mu \mathrm{l} / \mathrm{ml})$. Other media used under the same conditions and with the same additives were less effective or no more effective than $\alpha \mathrm{MEM}$.

\section{Preparation of collagen and collagen gels}

About $5 \mathrm{~g}$ of collagen from rat tail tendons extracted with $0.5 \mathrm{M}$ acetic acid at $4^{\circ} \mathrm{C}$ (Elsdale and Bard, 1972) were placed in 11. of $0.5 \mathrm{M}$ acetic acid for $48 \mathrm{~h}$ and the undissolved fibres allowed to sediment another $18 \mathrm{~h}$. The straw-coloured clear solution was poured off into separate $250-\mathrm{ml}$ bottles and kept on ice under ultraviolet light for $18 \mathrm{~h}$. This solution was operationally sterile, and was kept for over 1 year at $4^{\circ} \mathrm{C}$. The final solution contained about 0.1 per cent by weight of collagen.

In preparing the collagen gels, the gelation solution was made outside the culture dish by mixing $10 \times \mathrm{MEM}$ and $0.34 \mathrm{~N} \mathrm{NaOH}$ in a $2: 1$ ratio, and then adding $1.5 \mathrm{ml}$ of this cold mix to $6 \mathrm{ml}$ of cold collagen solution (Michalopoulos and Pitot, 1975). The $\mathrm{pH}$ was adjusted by adding drops of the mixture to the collagen solution until it was straw-coloured to light pink. The complete mixture was stirred well and syringed into the 24-well dish, placed at $37^{\circ} \mathrm{C}$ for $30 \mathrm{~min}$ for gels to form. The dishes were kept airtight at room temperature overnight until medium and cells were added.

\section{Assays of primary cultures from suspended cells}

Partially confluent cultures (5-6 wells with $16 \mathrm{~mm}$ diameters for each sample) were used to evaluate the effects of various hormones, media, reagents and substrates upon outgrowth of epithelial colonies. Although the colonies eventually became confluent under almost all conditions lested, they did not do so at the same rate. Staining the cultures with Giemsa solution (Fox, 1977) produced good definition of individual cells and nuclei and of colony formation. Stained cultures were analysed by a point lattice with each point $4 \mathrm{~mm}$ from adjacent points (Weibel, Kistler and Scherle, 1966). For all data, a $10 \times 10 \mathrm{~cm}$ lattice with 780 test points was placed on a print board, and the Giemsa-stained culture was projected by a photographic enlarger at $\times 8.5$ magnification upon the lattice so that the lattice overlaid the culture image and its corners touched the perimeter of the well image in all cases. The cultures were viewed first under the light microscope to determine if they were free of excess stain. The cellular and colony morpho- 
logies were clearly defined in images from the enlarger. The fraction of the 780 points which touched epithelial cells or colonies gave an estimation of fraction of the total $2 \mathrm{~cm}^{2}$ area of each well being covered by epithelial cells and colonies. This value I term the point-density fraction. Multiple counts of cell suspensions by haemocytometer were done before plating the cells at any particular density.

Selected cultures were tested histochemically for leucine aminopeptidase activity, which may discriminate between epithelial cells and fibroblasts (Marcelo et ai., 1978). This method entailed incubating freshly washed cultures in $1.25 \mathrm{ml}$ of a solution prepared by mixing $8 \mathrm{mg} / \mathrm{ml} \mathrm{1-leucyl-4-methoxy-B-naphthylamide-}$ $\mathrm{HCl}, 12.5 \mathrm{ml}$ of $0.1 \mathrm{M}$ phosphate buffer at $\mathrm{pH} 6.5$. $10 \mathrm{mll} 0.9$ per cent $\mathrm{NaCl}, 1.25 \mathrm{ml} 0.02 \mathrm{M} \mathrm{KCN}$ and $12.5 \mathrm{mg}$ of fast blue B. After incubating the culture for

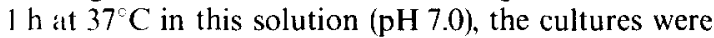
again washed with BSS and placed in a $0.2 \mathrm{M} \mathrm{CuSO}_{4}$ solution for several minutes and fixed over 2 per cent phosphate-buffered $\mathrm{OsO}_{4}$ before the cover-slip was applied.

\section{Hornones}

The media for primary cultures of suspended epithelial cells were supplemented either with insulin, hydrocortisone or both.

\section{Electron microscopy}

Preparation for electron microscopy was carried out in T-25 flasks or in 24-well dishes. Either phosphate or cacodylate-buffered 2 per cent glutaraldehyde was placed on the cultures for $2 \mathrm{~h}$; cultures were post-fixed with cacodylate-buffered 2 per cent osmium tetroxide, dehydrated with a graded series of isopropanol and infiltrated with Epon-Araldite (Mollenhauer, 1964). Thick sections were stained with 1 per cent toluidine blue and thin sections with lead citrate and uranyl acetate. The thin sections were viewed with an HU-11 Hitachi electron microscope at $75 \mathrm{kV}$.

\section{Substrates}

\section{RESLLTS}

Three-week-old tongue epithelia plated at $2.5 \times 10^{5}$ cells $/ \mathrm{cm}^{2}$ grew to confluency on collagen gels within two weeks in MEM/20 per cent FCS. Supplenenting medium with insulin $(15 \mu \mathrm{g} / \mathrm{ml})$ and hydrocortisone $(5 \mu \mathrm{g} / \mathrm{ml})$ brought these same cultures to confluency and stratification in 4 days. Cultures exhibited a "cobblestone" configuration by phase contrast microscopy (Plate Fig. 1). The collagen gels remained intact for only about three weeks after plating. Immediately after plating, some of the gels were loosened from the sides of the dish with a sterile scalpel to allow them to float free. Those gels not loosened disintegrated within 3-4 days. Free-floating gels underwent progressive shrinkage to about half their original diameter as the cells proliferated over a 3-week period, when they began to disintegrate also.

Plasma clots from chicken plasma and chick embryo extract, as well as polycarbonate filters $(0.2 \mu \mathrm{m}-0.8 \mu \mathrm{m}$ pore sizes) failed to support outgrowth under these growth conditions. Cellulose acetate-nitrate filters, especially the concave dull side of the $0.22 \mu \mathrm{m}$ pore size, supported epithelial growth, but not to confluency within one week. Colonies on filters could be viewed with a stereomicroscope and to some extent by transmission light microscopy after Giemsa staining (Plate Fig. 2). However, only plastic dishes gave good outgrowth as well as optical clarity for evaluation of epithelial growth (Plate Fig. 3). Therefore, subsequent experiments utilized the 24-well plastic dishes to standardize data for growth characteristics in the presence of hormones.

\section{Ultrastructural morphology of cultures}

Electron microscopy of one-week cultures demonstrated different patterns of stratification on the three different substrates. Those cultures on cellulose acetate-nitrate filters were usually monolayers and never more than two to three layers thick (Plate Fig. 4). Cultures on detached collagen gels were uniform and highly stratified (10-15 layers) within the first week of growth (Plate Fig. 5). The cultures on plastic dishes were intermediate with monolayers interspersed between areas of greater stratification (Plate Figs 3 and 6). Desmosomes were prominent at cell junctions in the lower strata of all cultures. Although well-defined hemidesmosomes were not prominent adjacent to any substrate, occasional condensations of filaments adjacent to the plastic substrate were suggestive of hemidesmosomes. Cell processes frequently projected into the cellulose acetate-nitrate filters or into the collagen gel matrices.

The basal cells on all three substrate were well preserved and flattened parallel to the surface. Rough endoplasmic reticulum was abundant in the lower 2 or 3 layers of all cultures. Cells of the superficial layers on plastic and collagen gel substrates contained a dense filamentous matrix. Fibroblasts were not observed in any specimen viewed by electron microscopy and were not demonstrable by the leucine aminopeptidase method.

\section{Growth conditions}

An initial experiment utilizing the point-density matrix (Plate Fig. 7) was performed to determine if insulin had any effect on the outgrowth of these epithelial cell cultures. Cultures plated at $5 \times 10^{5} \mathrm{cells} / \mathrm{cm}^{2}$ and grown for 3 days in MEM supplemented with both 10 per cent FCS and $10 \mu \mathrm{g} / \mathrm{ml}$ insulin grew to almost twice the density of cultures in MEM supplemented with only 10 per cent FCS (Table 1). When MEM was supplemented with only insulin or with neither FCS nor insulin, outgrowth density was less than a tenth that with MEM/10 per cent FCS.

Table 1. Effects of fetal calf serum and insulin on epithelial outgrowth

\begin{tabular}{lc} 
MEM + Additive & $\begin{array}{c}\text { Point-density fraction } \\
(\bar{x}+\text { SEM })\end{array}$ \\
\hline FCS $_{10^{*}}$ & $0.392 \pm 0.026$ \\
FCS $_{10}+\mathrm{I}_{10}$ & $0.589 \pm 0.013$ \\
$\mathrm{I}_{10^{\dagger}}$ & $0.028 \pm 0.003$ \\
$\mathrm{FCS}+\mathrm{I}_{0}$ & $0.010 \pm 0.003$
\end{tabular}

Cultures plated at $5 \times 10^{5}$ cells $/ \mathrm{cm}^{2}$ and grown in MEM for $72 \mathrm{~h}$ at $37^{\circ} \mathrm{C}$.

${ }^{*} \mathrm{FCS}_{10}=10$ per cent FCS.

$+I_{10}=10 \mu \mathrm{g} / \mathrm{ml}$ insulin. 
Table 2. Effects of various media on plating efficiency

\begin{tabular}{lc}
\hline \multicolumn{1}{c}{ Medium } & $\begin{array}{c}\text { Point-density fraction } \\
(\bar{x}+\text { SEM })\end{array}$ \\
\hline McCoy's 5A & $0.137 \pm 0.004$ \\
$\alpha$ MEM & $0.116 \pm 0.008$ \\
Medium 199 & $0.067 \pm 0.004$ \\
MEM & $0.054 \pm 0.004$ \\
Dulbecco's modif. & $<0.01$ \\
$\quad$ Eagle medium & \\
\hline
\end{tabular}

Cultures plated at $2.5 \times 10^{5} \mathrm{cells} / \mathrm{cm}^{2}$ and grown in medium plus 20 per cent $\mathrm{FCS}, 15 \mu \mathrm{g} / \mathrm{ml}$ insulin and $5 \mu \mathrm{g} / \mathrm{ml}$ hydrocortisone for $24 \mathrm{~h}$ at $37^{\circ} \mathrm{C}$.

When $2.5 \times 10^{5}$ cells $/ \mathrm{cm}^{2}$ cells were plated for $24 \mathrm{~h}$ in media containing 20 per cent $\mathrm{FCS}, 15 \mu \mathrm{g} / \mathrm{ml}$ insulin and $5 \mu \mathrm{g} / \mathrm{ml}$ hydrocortisone, McCoy's $5 \mathrm{~A}$ medium and $\alpha$ MEM gave much greater point-density fractions than other media (Table 2). Of the two best media, $\mathrm{MEM}$ was chosen for the remainder of the study. The effects of various concentrations of insulin upon plating efficiency were also compared (Text Fig. 8). The addition of either 40 or $400 \mu \mathrm{g} / \mathrm{ml}$ insulin to $\alpha \mathrm{MEM} / 10$ per cent $\mathrm{FCS}$ gave point-density fractions more than twice that of $\alpha \mathrm{MEM} / 10$ per cent FCS within the first $12 \mathrm{~h}$ after plating.

Four to five days after plating was arbitrarily chosen as a convenient time for confluence of plated cul-

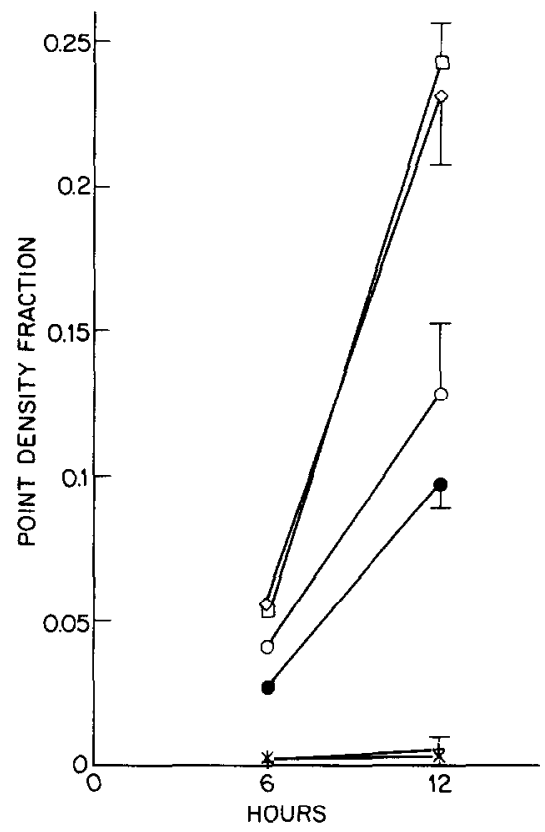

Fig. 8. The effects of FCS and/or various concentrations of insulin on plating efficiency. The result, expressed as the average point density fraction, is an estimate of the percentage of surface area covered by colonies. Each well contained $4 \times 10^{5} \mathrm{cells} / \mathrm{cm}^{2}$ in $\alpha \mathrm{MEM}$ which were supplemented as shown. $\longrightarrow, 10 \%$ FCS; $-0,10 \%$ $\mathrm{FCS}+4 \mu \mathrm{g} / \mathrm{ml}$ insulin; $\square-\square, 10 \% \quad \mathrm{FCS}+40 \mu \mathrm{g} / \mathrm{ml}$ insulin; $\diamond-\diamond, \quad 10 \% \quad \mathrm{FCS}+400 \mu \mathrm{g} / \mathrm{ml}$ insulin; $+\ldots+, 40 \mu \mathrm{g} / \mathrm{ml}$ insulin; $x-x, 400 \mu \mathrm{g} / \mathrm{ml}$ insulin). Vertical bars represent SEM. tures. An experiment was performed to determine the concentrations of cells which would grow to confluence in 5 days (Table 3). Cell concentrations of $1.25 \times 10^{5} / \mathrm{cm}^{2}$ and above became confluent within 5 days, but cultures plated below that concentration did not grow to confluency within 3 weeks.

Because DMSO was used by some investigators with epithelial explant cultures, comparison was made of epithelial outgrowth in hormone-supplemented media in the presence and absence of 0.5 per cent DMSO (Text Fig. 9). Cultures were fixed and stained 3 days after plating. DMSO supported no greater outgrowth of epithelial cultures and in most cases decreased the relative outgrowth when compared to cultures without DMSO. At the $1 \times$ hormonal concentrations (i.e. $4 \mu \mathrm{g} / \mathrm{ml}$ and $1.5 \mu \mathrm{g} / \mathrm{ml}$ of insulin and hydrocortisone, respectively), insulin plus hydrocortisone, and hydrocortisone alone, gave slightly better outgrowth than insulin alone. At the $100 \times$ hormonal concentrations, insulin plus hydrocortisone gave slightly better outgrowth than insulin or hydrocortisone alone. The best overall outgrowth was in cultures supplemented with $40 \mu \mathrm{g} / \mathrm{ml}$ insulin (in $\propto \mathrm{MEM} / 10$ per cent FCS). This was considerably better than when cultures were supplemented with $40 \mu \mathrm{g} / \mathrm{ml}$ insulin plus $15 \mu \mathrm{g} / \mathrm{ml}$ hydrocortisone, and almost twice as much as when $15 \mu \mathrm{g} / \mathrm{ml}$ hydrocortisone was the only hormone supplement. There were no morphological differences between the colonies after Giemsa staining.

To determine whether glucose enhances the action of insulin on these cultures, cells were plated in aMEM containing either $5.6 \mathrm{mM}$ glucose (formula level) or $20 \mathrm{mM}$ glucose with addition of insulin and/or FCS (Text Fig, 10). The cultures were observed at 1 day and 4 days after plating. At 1 day, high glucose medium supplemented with 10 per cent FCS plus $40 \mu \mathrm{g} / \mathrm{ml}$ insulin gave considerably better outgrowth than high glucose medium supplemented

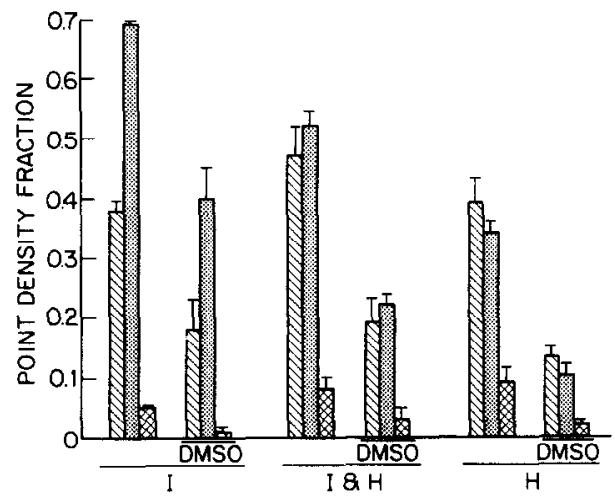

Fig. 9. The effects of hormone and DMSO supplements upon epithelial outgrowth. The results are expressed as the average point density fraction with SEM. Wells were plated with $5 \times 10^{5}$ cells $/ \mathrm{cm}^{2}$ in $\alpha \mathrm{MEM} / 10 \% \mathrm{FCS}$ and supplemented with insulin (I), hydrocortisone $(\mathrm{H})$ and insulin + hydrocortisone $(I$ and $H)$. DMSO $(0.5 \%)$ was also added to half the wells in each group as shown. Concentrations of insulin used were 4 (ख), 40 (圈) and 400 (용) $\mu \mathrm{g} / \mathrm{ml}$. Concentrations of hydrocortisone used were 1.5 (ख), $15($ 圆) and $150(\mathbb{\$}) \mu \mathrm{g} / \mathrm{ml}$. When used in combination, it was always in a ratio of $4: 1.5$, insulin to hydrocortisone, i.e., $4: 1.5 \mu \mathrm{g} / \mathrm{ml} ; 40: 15 \mu \mathrm{g} / \mathrm{ml}$ and $400: 150 \mu \mathrm{g} / \mathrm{ml}$. 


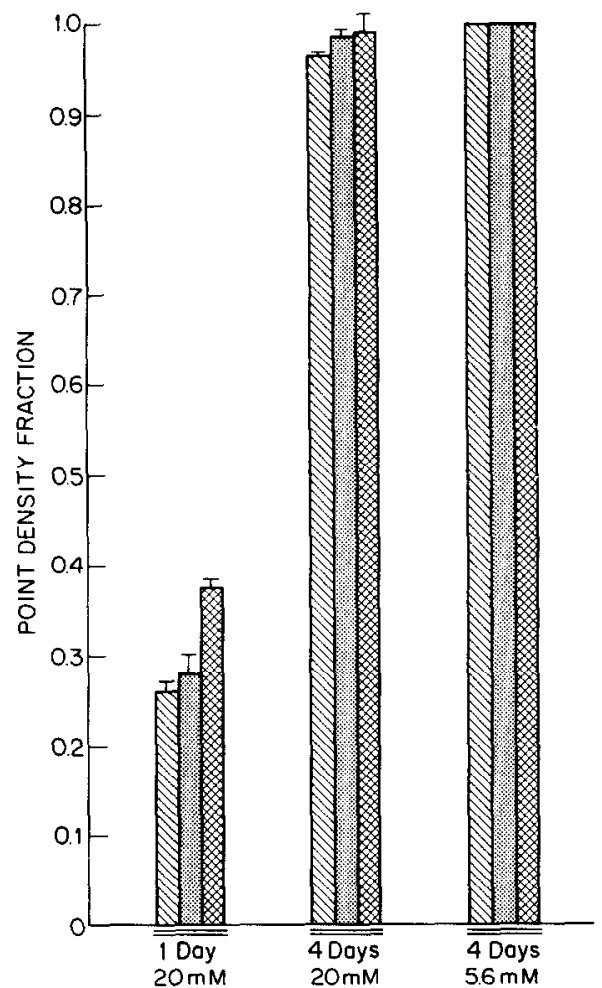

Fig. 10. The effects of 2 concentrations of glucose on epithelial outgrowth in the presence of insulin and/or FCS, the results are expressed as average point-density fraction with SEM. Wells were plated with $4 \times 10^{5}$ cells $/ \mathrm{cm}^{2}$ in $\alpha M E M$ containing either $5.6 \mathrm{mM}$ glucose or $20 \mathrm{mM}$ glucose and $10 \%$ FCS (⿴) $10 \%$ FCS $+4 \mu \mathrm{g} / \mathrm{ml}$ insulin (可) or $10 \%$ $\mathrm{FCS}+40 \mu \mathrm{g} / \mathrm{ml}$ insulin (国).

with either 10 per cent FCS or 10 per cent FCS plus $4 \mu \mathrm{g} / \mathrm{ml}$ insulin. These differences were reduced in the 4-day cultures. However, in cultures with the formula level of glucose, all wells reached confluency by 4 days, regardless of supplementation.

Another series of wells were plated with the same number of cells in $\alpha \mathrm{MEM}$, but without FCS, to determine if insulin without FCS, in the presence of elevated glucose, would enhance outgrowth (Text Fig. 11). As it has been suggested that the insulin effect in tissue culture may be due to trypsin-like proteolysis, soybean trypsin inhibitor (SBTI, $100 \mu \mathrm{g} / \mathrm{ml}$ ) was included in some of the wells. High-glucose medium supplemented with either 4 or $40 \mu \mathrm{g} / \mathrm{ml}$ insu-

Table 3. Effect of plating at various cell concentrations

\begin{tabular}{cc}
$\begin{array}{c}\text { Concentration of cells } \\
\left(\times 10^{5} / \mathrm{cm}^{2}\right)\end{array}$ & $\begin{array}{c}\text { Point-density fraction } \\
(\bar{x}+\text { SEM })\end{array}$ \\
\hline 5 & 1.00 \\
2.5 & 1.00 \\
1.25 & 1.00 \\
0.5 & $0.685 \pm 0.024$ \\
0.25 & $0.366 \pm 0.014$
\end{tabular}

Cultures grown for 5 days in $\alpha$ MEM plus 20 per cent FCS and $40 \mu \mathrm{g} / \mathrm{ml}$ insulin. lin did not increase colony outgrowth at 4 days over that at 1 day after plating. However, when SBTI was added, the outgrowth at 4 days was almost twice that at 1 day. This was still only about one-tenth the outgrowth observed at 4 days when $\alpha M E M$ was supplemented with 10 per cent FCS and insulin (Text Fig. 10). However, $\alpha$ MEM with formula-level glucose $(5.6 \mathrm{mM})$ and either 4 or $40 \mu \mathrm{g} / \mathrm{ml}$ insulin supported slightly more outgrowth at 4 days than high glucose media with the same insulin levels. Addition of SBTI to $40 \mu \mathrm{g} / \mathrm{ml}$ insulin resulted in twice as much outgrowth as with insulin alone within this 4 day period.

\section{DISCUSSION}

The trypsin method of separating epithelium from underlying connective tissue was similar to those reported by previous investigators (Vaughn et al., 1971; Marcelo et al., 1978) except that I incubated narrow slices ( $2 \mathrm{~mm}$ wide) of whole tissue with a solution of purified trypsin at $4^{\circ} \mathrm{C}$ rather than at $37^{\circ} \mathrm{C}$. and for a longer period $(18 \mathrm{~h})$. Lowering the temperature slows protease activity, but permits greater diffusion of aqueous solutions at the "undulating" epithelial-connective tissue interface (Szabo, 1955). Jensen and Moffet (1970), Briggaman, Dalldorf and Wheeler (1971) found that cold crude trypsin produces separation in the lamina lucida between basal cell plasma membrane and the basal lamina.

The plating method gave primary cultures morphologically similar to primary explant cultures in most respects. The major differences were that basal cells in explant cultures were slightly more ovoid than in plated cultures, the basal cells of explant cultures form prominent hemidesmosomes on the interface surface with the plastic substrate, explant cultures show greater stratification on comparable substrates and explant cultures can frequently be subcultured a number of times. All these characteristics suggest that enhanced differentiation of explant cultures might be attributed to the presence of fibroblasts, although difficult to find. Although fibroblasts are definitely present in early primary explant cultures of skin, tonguc and gingiva, they are difficult to demonstrate in confluent explant cultures. However, a major reason for greater differcntiation in cxplant cultures than in plated cultures may be the presence of fibroblasts in the explant cultures. The vigour of growth of both primary cultures and subcultures of human keratinocytes plated in the presence of irradiated 3T3 cells also supports this suggestion (Rheinwald et al.. 1975).

No investigator has reported the continuation of primary plated cell cultures of epithelial cells beyond about 6 weeks without the presence of connective tissue feeder cells. The end stages of the culture usually entail a loss of proliferative capacity, with gradual detachment of small groups or larger sheets of epithelium leaving either no cells or only flattened differentiated squames on the plastic surface (Fusenig et al.. 1975; Karasek, 1975). To test the hypothesis that this degeneration of stratified epithelial cultures might be due either to inability of nutrient media to reach the basal cells, or to restricted media in combination with less than adequate substrate, I grew the cells on cellulose acetate-nitrate filters and collagen gels. The filter permitting the best growth $(0.22 \mu \mathrm{m}$ pore size $)$ gave no 
better growth than plastic substrate, suggesting that culture degeneration did not result from basal cell starvation. Plated epithelial cultures grown over 6 days on collagen gels always developed more strata than on plastic or filters. This is consistent with improved cell and tissue histodifferentiation of both rat hepatocytes and mouse mammary gland epithelium on floating collagen gels (Michalopoulos et al., 1975; Emerman et al., 1977). It can be hypothesized that the floating collagen "membrane" gives the cells anchorage and at the same time permits them to aggregate and morphodifferentiate without severing attachment to the substrate. In the case of hepatocytes and mammary epithelium, as well as rat tongue epithelium in my study, contraction of the collagen gel occurs when floating gels are seeded with cells. The deterioration of cell-plated collagen gels after about three weeks of culture suggested that the plated epithelial cultures elaborated substances with collagenolytic activity as Eisen and Gross (1965) and Grillo and Gross (1967) described for marginal wound epithelium in guineapigs and for amphibian epithelium.

I found that the addition of insulin enhances the outgrowth of the cultures compared with media supplemented only with FCS (Table 1) which contains approximately $3.5 \mu \mathrm{IU} / \mathrm{ml}$ of insulin (Bernaert et al., 1977). Insulin target cells, such as isolated fat cells, exhibit high affinity binding of insulin to plasma membrane receptors at concentrations of about $0.1 \mathrm{nM}$ or $15 \mathrm{nIU} / \mathrm{ml}$ which is within the physiologic range (Cuatrecasas, 1974). For some cell types in culture such as chick-embryo fibroblasts, 3T3 mouse fibroblasts and human fibroblasts, insulin can either substitute for serum or can enhance the DNA synthetic stimulatory response to serum (Temin, 1967; Goldberg et al., 1974; Hollenberg and Cuatrecasas, 1975b). Insulin also stimulates DNA synthesis of cultured rabbit lens cells (Reddan et al., 1975) and differentiation of embryonic-chick lens epithelium (Milstone and Piatigorsky, 1977). However, the concentrations used in tissue culture are frequently in the range of $1-10 \mu \mathrm{g} / \mathrm{ml}(1 \mu \mathrm{M}$ or $150 \mu \mathrm{IU} / \mathrm{ml}$ range). Hollenberg and Cuatrecasas suggested that this large amount of insulin may be necessary in tissue culture because either the response is due to a contaminant in the insulin preparation, insulin shares some crossreactivity with another, more active growth factor, or is due to proteolytic action by insulin rather than receptor interaction (Hollenberg and Cuatrecasas, 1975a). I used soybean trypsin inhibitor to determine whether insulin's effects on the cultures was due to its protease activity. Rather than diminishing growth, SBTI enhanced colony outgrowth to twice that observed in cultures supplemented with insulin alone (Text Fig. 11), suggesting that either the commercial SBTI is contaminated with other stimulatory proteins (Kassell, 1970) or stimulation of growth of rat lingual epithelium by insulin is not through its proteolytic properties.

By itself, hydrocortisone $(15 \mu \mathrm{g} / \mathrm{ml})$ stimulated outgrowth of epithelial colonies to only about half the area covered by insulin-treated cultures (Text Fig. 9). Hydrocortisone is generally considered to be antagonist to insulin, both in its hyperglycaemic effect and inhibition of macromolecular synthesis. Hydrocortisone inhibits DNA synthesis and mitoses in mouse epidermis (Hennings and Elgjo, 1971), in liver cells in vivo and in vitro (Loeb, 1976; Murison, 1976) and in human mammary gland cells in vitro (Flaxman, 1973). However, hydrocortisone has DNA synthetic stimulatory effects on human diploid skin fibroblasts (Macieira-Coelho, 1966) and human lung diploid fibroblasts (Cristofalo, 1974) among others.

As with insulin, the exact methods of action of hydrocortisone are unknown. Contrary to insulin, hydrocortisone passes easily through the cell membrane and binds to protein receptors in the cell cytoplasm (Tomkins, 1974). The beneficial effects of hydrocortisone in culture are in its ability to promote differentiation and to prolong the life of the cultures. Prolongation of culture life span was observed in rat hepatocytes in culture by Michalopoulos, Sattler and Pitot (1978), WI-38 lung fibroblasts by Cristofalo (1974) and human keratinocytes in culture (Rheinwald et al., 1975) supplied with hydrocortisone or synthetic glucocorticoid substitutes. Hydrocortisone also enhances keratinization in explants of whole embryonic chick skin in chemically defined media (Kojima, Sugimoto and Endo, 1976) and u.v.-light-injured fetal rat skin in culture (Weissmann and Fell, 1962). The differentiation effects of hydrocortisone on whole skin or on keratinocytes fed by $3 \mathrm{~T} 3$ cells may be related to its effects on the underlying connective tissue. Chick embryos treated with hydrocortisone $12-24 \mathrm{~h}$ hefore feather-germ formation fail to form normal dermal cell orientation, banding, mitotic activity and dermal papillae, possibly because the steroid interferes with organization of the collagen lattice. Subsequently, there is epidermal thickening but not feather morphogenesis (Stuart, Garber and Moscona, 1972).

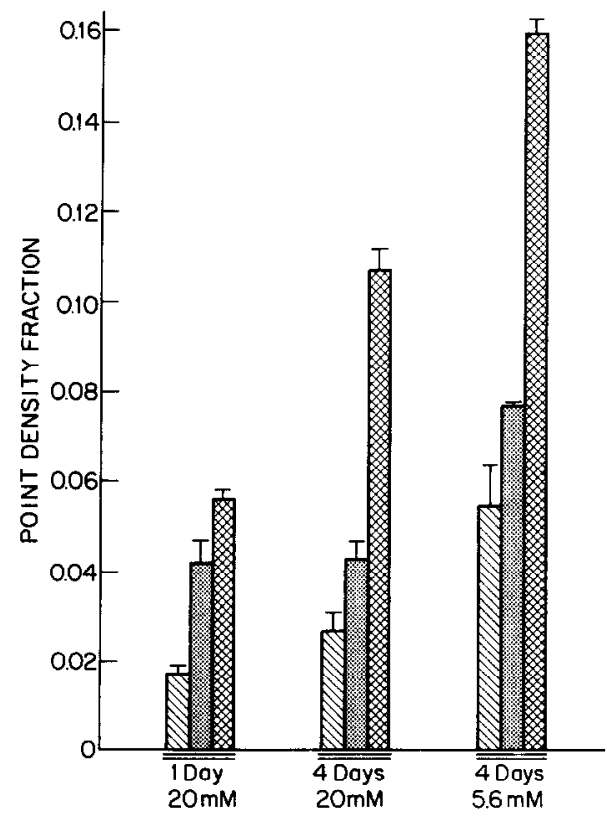

Fig. 11. The effects of 2 concentrations of glucose on epithelial outgrowth in presence of insulin, but not FCS. The results are expressed as average point density fraction with SEM. The wells were plated with $4 \times 10^{5} \mathrm{cells} / \mathrm{cm}^{2}$ in $\alpha$ MEM containing either $5.6 \mathrm{mM}$ glucose or $20 \mathrm{mM}$ glucose and $4 \mu \mathrm{g} / \mathrm{ml}$ insulin (因), $40 \mu \mathrm{g} / \mathrm{ml}$ insulin (圆), or $40 \mu \mathrm{g} / \mathrm{ml}$ insulin $+100 \mu \mathrm{g} / \mathrm{ml}$ soybean trypsin inhibitor 
I found that addition of DMSO diminished colony outgrowth compared with either insulin or hydrocortisone without DMSO. If insulin normally exerts its growth-stimulating effects in culture through proteolysis of cell membranes, perhaps DMSO, acting as a solvent (Rammler and Zaffaroni, 1967), carries insulin through the plasma membrane before it can act on the membrane. An alternative explanation might be that, as an aprotic solvent which accepts rather than donates protons, it inhibits enzymic proteolysis. Gerhards and Gibian (1967) showed that intrinsic trypsin-like and chymotrypsin-like activity in rat liver slices is reduced in the presence of DMSO. DMSO may increase transport efficiency of hydrocortisone and simply enhance the inhibitory effect of this molecule on epithelial outgrowth.

Insulin in a glucose-enriched medium has beneficial effects on morphology, DNA synthesis and colony outgrowth for several cell types including $\mathrm{C} 3 \mathrm{H}$ mouse mammary cells and hepatocytes (Skarda et al., 1974; Bernaert et al., 1977) I found that $20 \mathrm{mM}$ glucose did not benefit colony outgrowth more than the formula level of $5.6 \mathrm{mM}$, suggesting that even if insulin were to entance glucose transport in lingual epithelium, an inceased energy source is probably of secondary importance compared with plasma membrane receptors or a proteolytic stimulating effect for cell proliferation and colony outgrowth

Although explant cultures favour greater morphodifferentiation of rat tongue epithelium, plated cultures have other advantages. By varying the plating der sity, the rate at which a culture becomes confluent car be controlled and cell or colony density at various stages of growth is easier to measure. Although growth media and conditions used for plated cultures probably favour proliferation more than differentiation, this system offers the opportunity to test the effects of many different materials upon proliferation and subsequent differentiation. In future, the minimal number of contiguous epithelial cells may be determined e.g., the approximate number of epithelial cells per cluster, necessary in a supplemented culture and on an adequate substrate to develop a morphodifferentiated epithelium resembling the in vivo appearance (Billingham et al., 1967).

Achnowledgements 1 wish to thank W. Wagaw, Dr. E. Smith and Ms. R. Ikerd for laboratory assistance and Ms P. Butts and Ms. K. Tierney for typing the manuscript Ihis study was supported in part by Grant number 5-Si)7-RR05321-17, awarded by the Biomedical Research Support Program of the Division of Research Resources USPIIS, and in part by a Faculty Development Award from Horace H. Rackham. School of Graduate Studies University of Michigan.

\section{REFERENCES}

Bernaert D.. Wanson J. C., Drochmans P. and Popowski A. 1977. Effect of insulin on ultrastructure and glycogenesis in primary cultures of adult rat hepatocytes. $J$. Cell Biol. 74, 878-900.

Bernfield M. R. 1970. Collagen synthesis during epitheliomesenchymal interactions. Dev/ Biol. 22, 213-231.

Billingham R. E. and Silvers W. K. 1967. Studies on the conservation of epidermal specificities of skin and certain mucosas in adult mammals. J. exp. Med. 125 , $429-446$
Briggaman R. A., Dalldorf F. C. and Wheeler C. E. 1971. Formation and origin of basal lamina and anchoring fibrils in adult human skin. $J$. Cell Biol. 51, 384-395.

Briggaman R. A. and Wheeler C. E. 1971. Epidermal dermal interactions in adult human skin. J. imest. Derm. 56. $18-26$.

Cristofalo V. J. 1974. Hydrocortisone as a modulator of cell division and population lifespan. Adv expl med. Biol. 44. 57-79.

Cuatrecasas P. 1974. Insulin receptors, cell membranes and hormone action. Biochem. Pharmac. 23, 2353-2361.

Eisen A. Z. and Gross J. 1965. The role of epithelium and mesenchyme in the production of a collagenolytic enzyme and a hyaluronidase in the anuran tadpole. Dev Biol. 12, 408418

Elsdale T. and Bard J. 1972. Collagen substrata for studies on cell behavior. $J$. Cell Biol. 54, 626-637.

Emerman J. T., Enami J., Pitelka D. R. and Nandi S. 1977. Hormonai effects on intracellular and secreted casein in cultures of mouse mammary epithelial cells on floating collagen membranes. Proc. natl Acad. Sci. 74, 4466-4470

Farb R. M., Dykes R. and Lazarus G. S. 1978. Anti-epidermal-cell surface pemiphigus antibody detaches viable epidermal cells from culture plates by activation of proteinase. Proc. nat Acad. Sci. 75, 459-463.

Flaxman B. A. 1973. In vitro studies of the human mammary gland; effect of hormones on proliferation in primary cell cultures. $J$. intest. Derm. 61, 67.71.

Fox C. H. 1977. Staining cultures of cells. In: Tissue Culture Association Manual, Vol. 3 (Edited by Evans V. J. Perry V. P. and Vincent M. M.). pp. 583-585. Tissue Culture Association, Rockville, Maryland.

Fusenig N. E. and Worst P. K. M. 1975. Mouse epidermal cell cultures. II. Isolation, characterization and cultivation of epidermal cells from perinatal mouse skin. Expl. Cell Res. 93, 443-457.

Gcrhards E. and Gibian II. 1967. The metabolism of dimethyl sulfoxide and its metabolic effects in man and animals. Ann. N.Y. Acad. Sci, 141. 65-76.

Goldberg N. D., Haddox M. K., Dunham E., Lopez C. and Hadden J. W. 1974. The yin yang hypothesis of biological control: opposing influences of cyclic GMP and cyclic AMP in the regulation of cell proliferation and other biological processes. In: Control of Proliferation in Animal Cells (Edited by Clarkson B. and Baserga R.). pp. 609-625. Cold Spring Harbor Laboratory.

Grillo H. C. and Gross J. 1967. Collagenolytic activity during mammalian wound repair. Devl Biol. 15, 300-317.

Hallowes R. C., Rudland P. S., Hawkins R. A., Lewis D. J., Bennett D. and Durbin H. 1977. Comparison of the effects of hormones on DNA synthesis in cell cultures of nonneoplastic and neoplastic mammary epithelium from rats. Canc. Re's. 37, 2492-2504.

Hennings $H$. and Elgjo K. 1971. Hydrocortisone: inhibition of DNA synthesis and mitotic rate after local application to mouse epidermis. Virchows Arch. Abt. B. Zellpath. 8, 42.49

Hollenberg M. D. and Cuatrecasas P. 1975a. Insulin: interaction with membrane receptors and relationship to cyclic purinc nucleotides and cell growth. Fedn Proc. Fedn Am. Socs exp. Biol. 34, 1556-1563.

Hollenberg M. D. and Cuatrecasas P. 1975b. Insulin and epidermal growth factor: human fibroblast receptors related to deoxyribonucleic acid synthesis and amino acid uptake. J. hiol. Chem. 250. 3845 .3853.

Ijuhin N.. Rose G. G. and Mahan C. J. 1976. The subcellular organization of human gingival epithelium cultivated in circumfusion systems. Archs. oral Biol. 21, 571- 582.

Jensen J. and Moffet N. 1970. Ultrastructural changes in keratinizing epithclium following trypsinization, epidermal detachment and apposition to mesenchymes. J. Cell Sci. 6, $511-535$. 
Jepsen A. 1974. An in vitro model of an oral keratinizing squamous epithelium. Scand. J. dent. Res. 82, 144-146.

Karasek M. A. 1975. In vitro growth and maturation of epithelial cells from post-embryonic skin. $J$. invest. Derm. 65. 60-66.

Kassell B. 1970. Trypsin and chymotrypsin inhibitors from soybeans. In: Methods in Enzymology, Vol. 19 (Edited by Perlman G. E. and Lorand L.) pp. 853-862. Academic Press, New York.

Kojima A., Sugimoto M. and Endo H. 1976. Epidermal protein metabolism directed toward keratinization of hydrocortisone in the chick embryonic skin growing in a chemically defined medium. Devl Biol. 48, 173-183.

Loeb J. N. 1976. Corticosteroids and growth. New Engl. J. Med. 295, 547.-552.

Macieira-Coelho A. 1966. Action of cortisone on human fibroblasts in vitro. Experientia 22, 390-391.

Marcelo C. L.. Kim Y. G., Kaine I. L. and Vonrhees I. J. 1978. Stratification, specialization and proliferation of primary keratinocyte cultures. $J$. Cell Biol. 79. 356-370.

Michalopoulos G. and Pitot H. C. 1975. Primary culture of parenchymal liver cells on collagen membranes. Expl Cell Res. 94, 70-78.

Michalopoulos G., Sattler G. L. and Pitot H. C. 1978. Hormonal regulation and the effects of glucose on tyrosine aminotransferase activity in adult rat hepatocytes cultured on floating collagen membranes. Canc. Res. 38, $1550-1555$.

Milstone L. M. and Piatigorsky J. 1977. $\delta$-Crystallin gene expression in embryonic chick lens epithelia cultured in the presence of insulin. Expl Cell Res. 105, 9-14.

Mollentauer H. H. 1964. Plastic embedding mixtures for use in electron microscopy. Stain Technol. 39, 111-114.

Murison G. L. 1976. Growth of fetal rat cells in response to hydrocortisone. Exp/ Cell Res. 100, 439-443.

Nordling S., Ekblom P., Lehtonen E., Saxén L. and Wartiovaara J. 1977. Kidney tubule induction: physical and chemical interference. In: Cell Inteructions in Differentiation (Edited by Karkinen-Jääskeläinen M. and Saxén L.), pp. 249-261. Academic Press, New York.

pardee A. R. 1975. The cell surface and fibroblast proliferation: some current research trends. Biochim. biophys. Acta 417, 153 172.

Pictet R. L., Filosa S., Phelps P. and Rutter W. J. 1975. Control of DNA synthesis in the embryonic pancreas: interaction of mesenchymal factor and cyclic AMP. In: Extracellular Matrix Influences on Gene Expression (Edited by Slavkin $H$. C. and Greulich R. C.), pp. 531-540. Academic Press, New York.
Pruniéras M., Delescluse C. and Regnier M. 1976. The culture of skin: a review of theories and experimental methods. $J$. invest. Derm. 67, 58-65.

Rammler D. H. and Zaffaroni A. 1967. Biological implications of DMSO based on a review of its chemical properties. Ann. N.Y. Acad. Sci. 141, 13-23.

Reddan J. R., Unaker N. J., Harding C. V., Bagchi M. and Saldàna G. 1975. Induction of mitosis in the cultured rabbit lens initiated by the addition of insulin to medium KEI-4. Expl. Eye Res. 20, 45-61.

Rheinwald J. G, and Green H. 1975. Serial cultivation of strains of human epidermal keratinocytes: the formation of keratinizing colonies from single cells. Cell $\mathbf{6}$, 331-344.

Richman R. A., Claus T. H., Pilkis S. G. and Friedman D. L. 1976. Hormonal stimulation of DNA synthesis in primary cultures of adult rat hepatocytes. Proc. nat Acad. Sci. 73, 3589-3593.

Skarda J., Green C. D., Aisbitt P. G. and Barry J. M. 1974. Insulin does not stimulate DNA synthesis in cultured mammary tissue by enhancing glucose uptake. $J$. Endocr. 60, 197-198

Stuart E. S. Garber B. and Moscona A. A. 1972. An analysis of feather germ formation in the embryo and in titro. in normal development and in skin treated with hydrocortisone. J. expl. Zool. 179, 97-118.

Szabo F. 1955. A modification of the technique of "skin splitting" with trypsin. J. Path. Bact. 70, 545

Temin H. M. 1967. Studies on carcinogenesis by avian sarcoma viruses: Vl. Differential multiplication of unaffected and of converted cells in response to insulin. $J$. Cell Phusiol. 69, 377-384.

Tomkins G. M. 1974. The molecular biology of the steroid hormones. Adv. expl. med. Biol. 44, 357-365.

Vaughn F. L. and Bernstein 1. G. 1971. Studies of proliferative capabilities in isolated epidermal basal and differentiated cells. J. invest. Derm. 56, 454-466.

Weibel E. R.. Kistler G. S. and Scherle W. F. 1966. Practical stereological methods for morphometric cytology. $J$. Cell Biol. 30, 23-38.

Weiss P. and Matoltsy A. G. 1959 . Wound healing in chick embryos in vivo and in vitro. Dev/ Biol. 1, 302-326.

Weissmann G. and Fell H. B. 1962. The effect of hydrocortisone on the response of fetal rat skin in culture to ultraviolet irradiation. J. expl. Med. 116, 356 380.

Wessells N. K. 1964. Substrate and nutrient effects upon epidermal basal cell orientation and proliferation. Proc. natl Acad. Sci. 52, 252-259. 
Cultured epithelial cell growth

Plates 1 and 2 overleaf. 
Plate 1.

Fig. 1. Phase contrast micrograph of rat tongue epithelial cell culture supplemented with insulin and hydrocortisone and on floating collagen gel 4 days after plating. The cultures were confluent and the cells had a cobblestone configuration, $\times 100$

Fig. 2. Rat tongue epithelial cell culture with hormonal supplements on $0.22 \mu \mathrm{m}$ cellulose acetate nitrate filter 4 days after plating. Although the culture was not confluent, the epithelial cells were grouped in large sheets. Giemsa stain. $\times 100$

Fig. 3. Rat tongue epithelial cell culture with hormonal supplements on plastic substrate 4 days after plating. The culture was confluent and exhibited monolayers of cells interspersed between ridges of highly stratified cells (arrow). Giemsa stain. $\times 100$

Plate 2.

Fig. 4. Electron micrograph of epithelial culture on $0.22 \mu \mathrm{m}$ cellulose acetate-nitrate filter from Fig. 2. There are 3 to 4 layers of cells with desmosomes between cells of each layer. Basal cells have nuclei (N) elongated parallel to the filter and have extensions of cytoplasmic membrane projecting into the filter pores (arrow). Bar represents $1 \mu \mathrm{m} \times 9000$

Fig. 5. Epithelial cuiture on collagen gel from Fig. 1. At least 10 cell layers are present with healthy nuclei in the first 2 or 3 layers and elongated parallel to the surface of the collagen gel (G). Superficial layers contains pyknotic nuclei $(\mathrm{P})$ and desquamating cells. Bar represents $1 \mu \mathrm{m} \times 4500$

Fig. 6. Epithelial cells on plastic substrate from Fig. 3. This section is from a more stratified area. Two zones are evident: the lower 2 or 3 layers of cells containing a ribosome-rich cytoplasm and viable nuclei (N) and the upper layers with numerous cytoplasmic filaments, sometimes a few pyknotic nuclei, and desquamating cells (D). Bar represents $\mathrm{l} \mu \mathrm{m} \times 6000$

Fig. 7. Point-density matrix superimposed on subconfluent epithelial culture in 16-mm well. Each well, stained with Giemsa, was projected onto the $10 \mathrm{~cm}^{2}$ matrix. $\times 0.38$ 


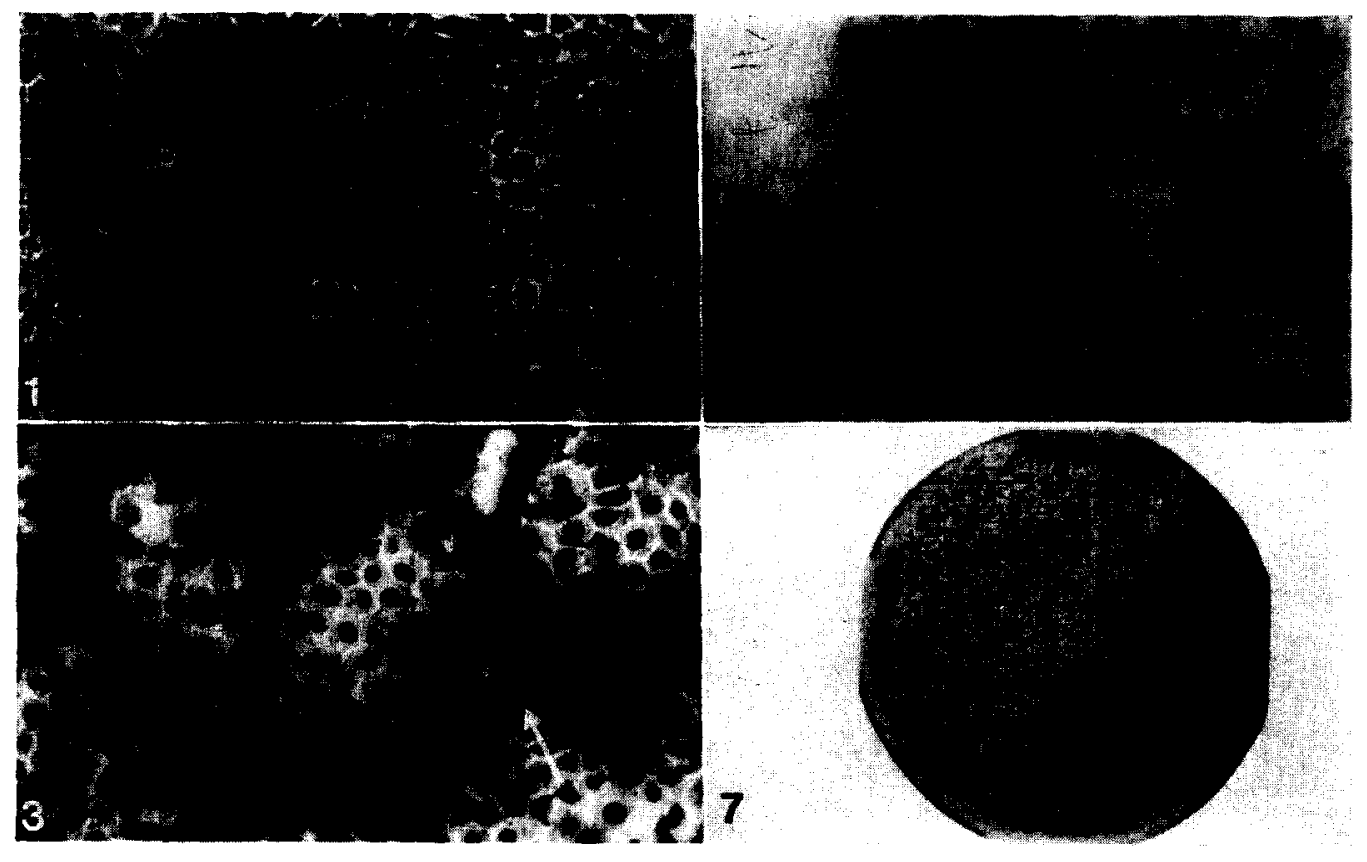

Plate 1. 


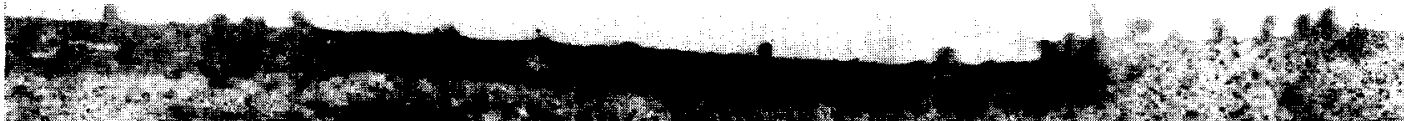

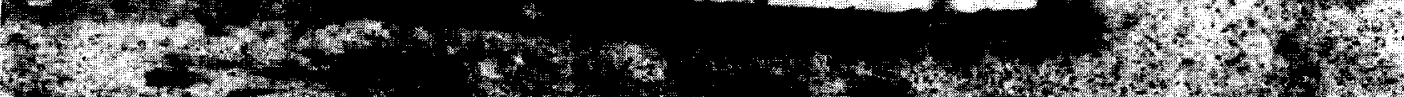

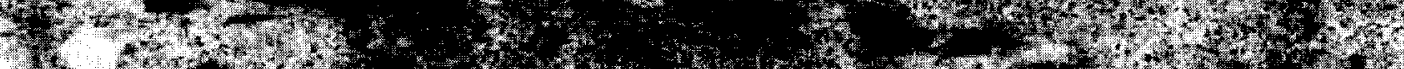

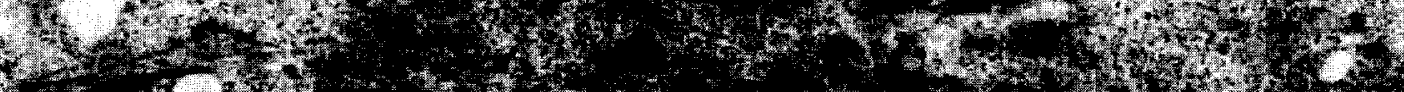

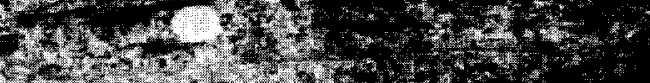

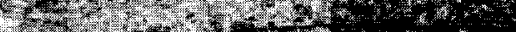

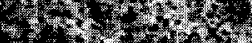

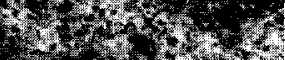

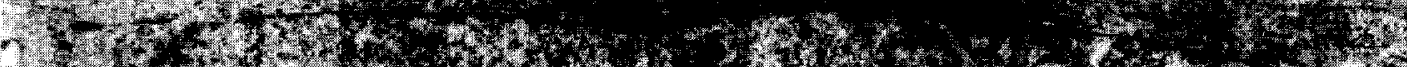

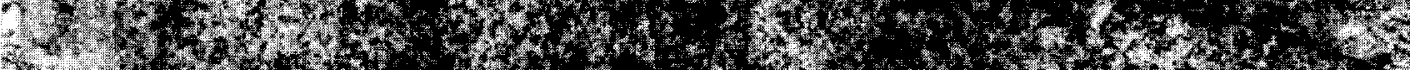

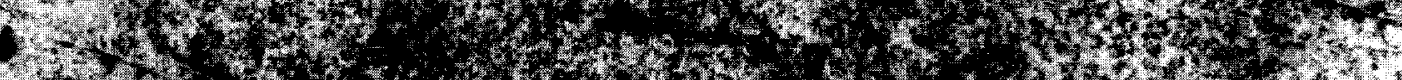

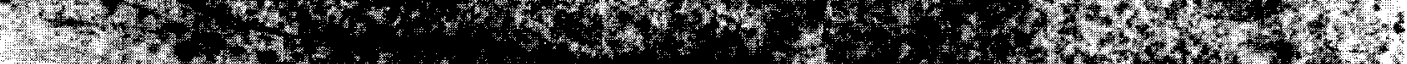
my

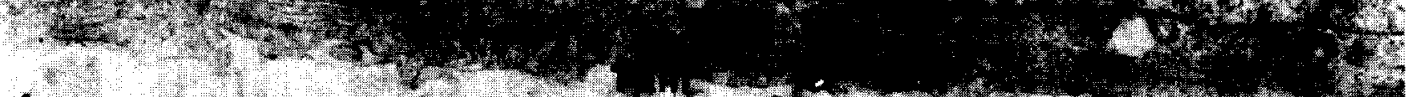
4 (1)

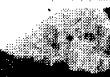

\section{4}

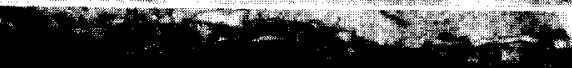
$4(3)$
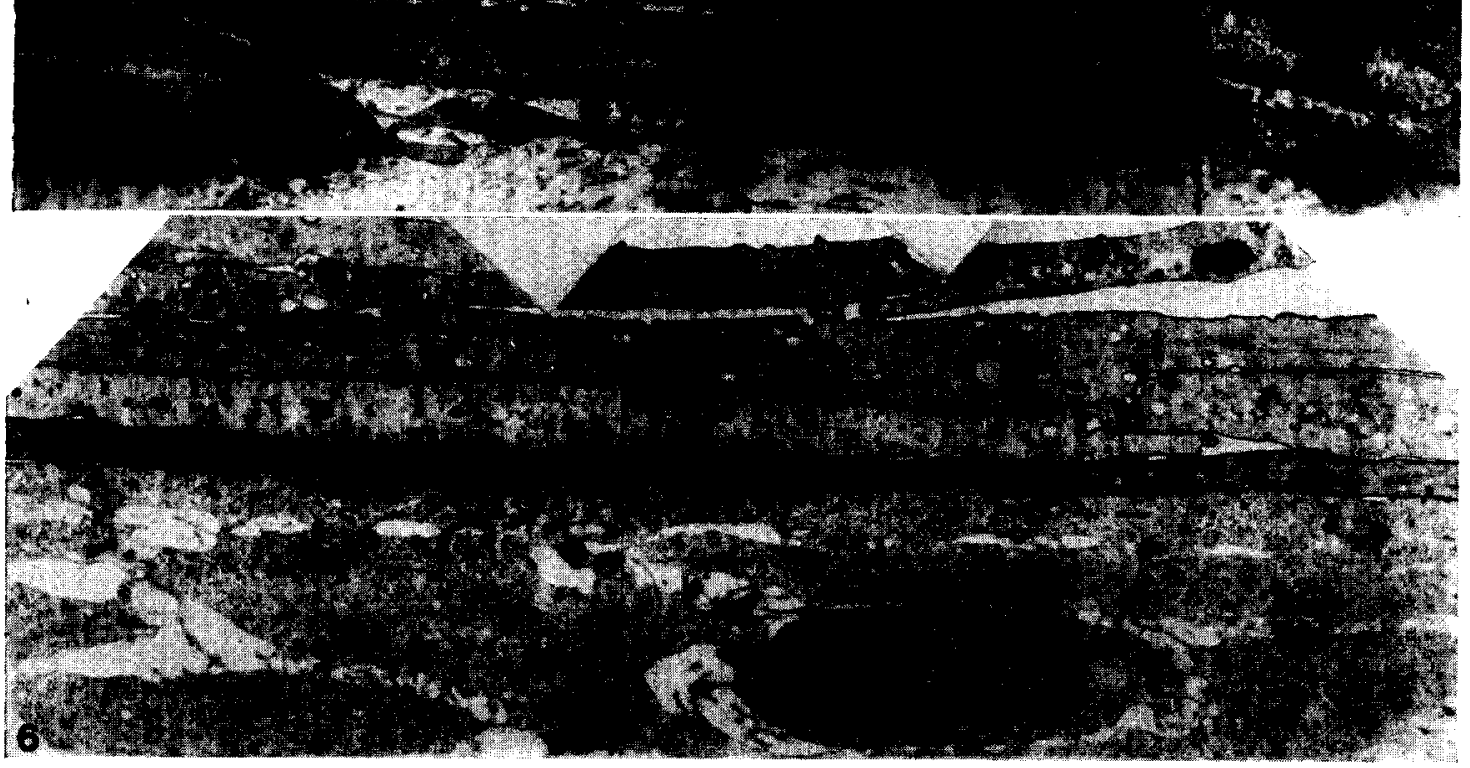

Plate 2. 